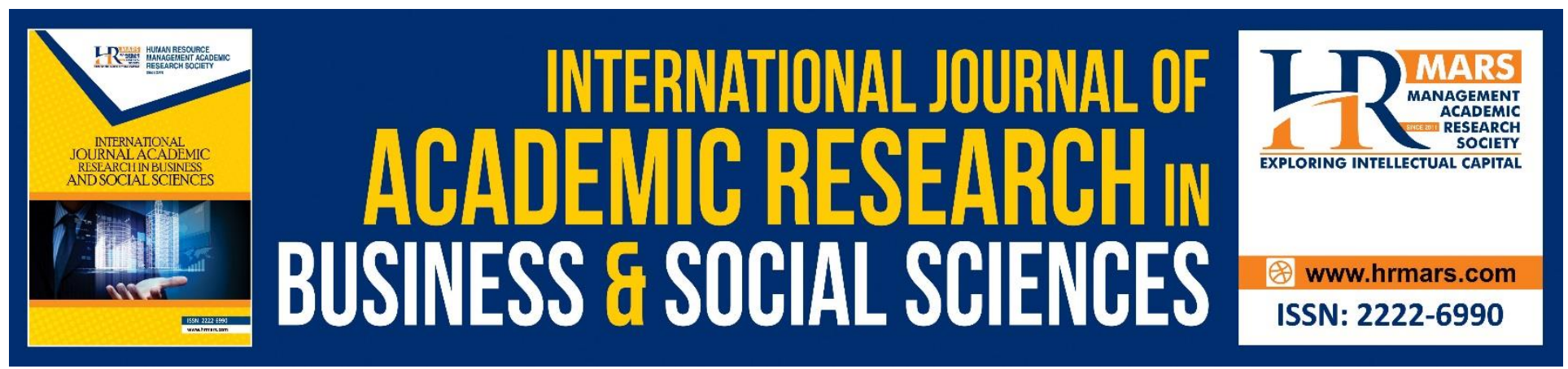

\title{
Semantics in MH17 Tragedy Newspaper News
}

Sharil Nizam Sha'ri, Nor Azuan Yaakob, Mohd Hazreen Shah Hassan Mohamad Suhaizi Suhaimi, Nor Azira Che Ramely, Zuraini Seruji, Rahmah Abd Ghani

To Link this Article: http://dx.doi.org/10.6007/IJARBSS/v10-i8/7670 DOI:10.6007/IJARBSS/v10-i8/7670

Received: 19 May 2020, Revised: 21 June 2020, Accepted: 23 July 2020

Published Online: 30 August 2020

In-Text Citation: (Sha'ri, Yaakob, Suhaimi, Ramely, Seruji, Abd Ghani, 2020)

To Cite this Article: Sha'ri, S. N., Yaakob, N. A., Suhaimi, M. H. S. H. M. S., Ramely, N. A. C., Seruji, Z., Abd Ghani, R. (2020). Semantics in MH17 Tragedy Newspaper News. International Journal of Academic Research in Business and Social Sciences. 10(8), 1008-1025.

Copyright: (C) 2020 The Author(s)

Published by Human Resource Management Academic Research Society (www.hrmars.com)

This article is published under the Creative Commons Attribution (CC BY 4.0) license. Anyone may reproduce, distribute, translate and create derivative works of this article (for both commercial and non-commercial purposes), subject to full attribution to the original publication and authors. The full terms of this license may be seen

at: http://creativecommons.org/licences/by/4.0/legalcode

Vol. 10, No. 8, 2020, Pg. 1008 - 1025

http://hrmars.com/index.php/pages/detail/IJARBSS

JOURNAL HOMEPAGE

Full Terms \& Conditions of access and use can be found at http://hrmars.com/index.php/pages/detail/publication-ethics 


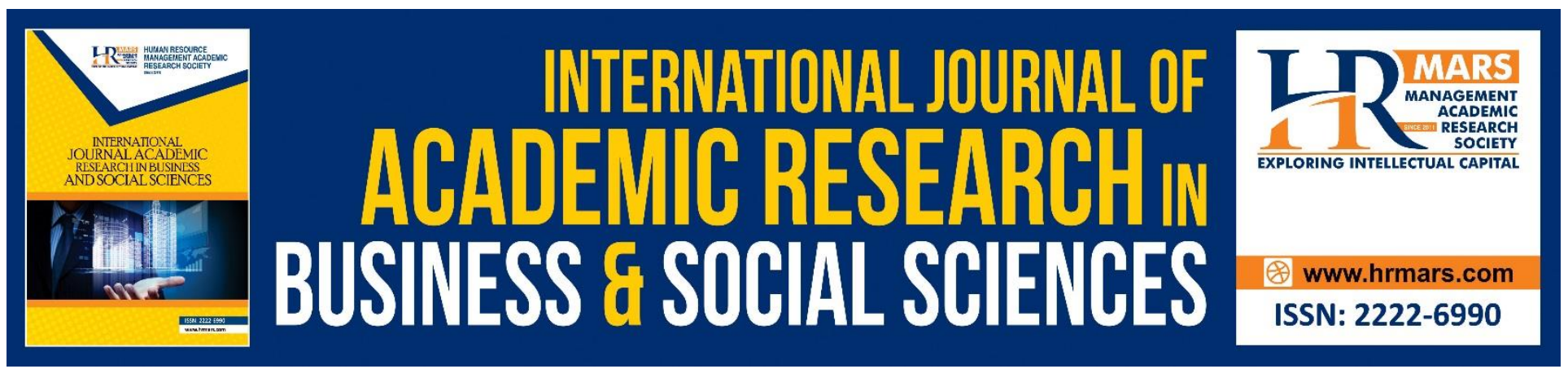

\title{
Semantics in MH17 Tragedy Newspaper News
}

\author{
Sharil Nizam Sha'ri, Nor Azuan Yaakob, Mohd Hazreen Shah \\ Hassan Mohamad Suhaizi Suhaimi, Nor Azira Che Ramely \\ Department of Malay Language, Faculty of Modern Languages and Communication \\ Universiti Putra Malaysia, 43400 Serdang, Selangor
}

\author{
Zuraini Seruji \\ Faculty of Language and Communication, Universiti Malaysia Sarawak \\ 94300 Kota Samarahan, Sarawak, Malaysia. \\ Rahmah Abd Ghani \\ Institut Pendidikan Guru Kampus Gaya, Kota Kinabalu, Sabah
}

\begin{abstract}
This study is an observation of the use of semantic elements to online newspaper news about the plane crash that has claimed many lives, namely the MH17 Tragedy. The important purpose is to look at the problem of ambiguity of meaning that occurs. In addition, this study also explains the use of semantic elements in newspaper news that can cause changes in the original meaning according to the context of the sentence used. as the main source of information. This study focuses primarily on semantics in online newspaper news by using structural semantic theory approach by (Katz, 1972). This theory emphasizes the meaning of each word based on the sentence used. To achieve that goal, the study was based on identifying semantics and newspaper news. Next make a comparison between the newspaper and describe the semantic meaning in the newspaper news. Through this study, the researcher has used two main newspapers, namely Berita Harian and Utusan Malaysia. A total of 14 newspapers were used as study data, namely seven newspapers were from Berita Harian and seven more were from Utusan Malaysia. Next, the researcher only selected six newspapers to explain the meaning, namely three newspapers from Berita Harian and three more from Utusan Malaysia.
\end{abstract}

Keyword: Semantic, MH17 Tragedy, Online Newspaper, Original Meaning, Ambiguity of Meaning.

\section{Introduction}

Semantics not only studies the meaning of words, phrases and sentences but also studies the relationship between different linguistic expressions such as homonyms, synonyms, antonyms, polysemy, homonyms and hyponyms. Semantic studies also involve the study of semantic roles, meanings and references, true conditions and discourse analysis. Semantics has its developmental 
stage. The first level is philosophical semantics and then the second level which is linguistic semantics. The field of semantics is considered a field that is difficult to learn and explore because the field studies meaning, whether at the word or sentence level. Researchers need to consider non-linguistic aspects, such as the way the sentence is pronounced or used, the change of meaning according to the context of the utterance, the psychological aspects of the speaker, the nature of his thinking, the social relationship between the speaker and the listener and the topic of discussion (Hamzah, 2014). In this study, the semantic aspect is studied based on the $\mathrm{MH} 17$ tragedy news report in Berita Harian and Utusan Malaysia which causes various situations to occur to the heirs, the people and the country.

\section{Statement of Problem}

This section discusses the problem statement related to the ambiguity of meaning, change of meaning according to the context and speech situation, readers also share their feelings on the $\mathrm{MH} 17$ Tragedy incident as well as online news (e-newspaper) read only by a few people.

Firstly, the ambiguity of meaning in the Berita Harian and Utusan Malaysia newspapers. The statement of the problem that exists through the semantic study in the MH17 Tragedy newspaper news is that there is an ambiguity of meaning in the newspaper news. Newspaper news is a written report that explains the facts about an issue. The issue should be conveyed through denotative aspects that emphasize the facts and conveyed directly to the reader without having to think about the meaning of the sentence. The sentences in the news report need to be easily understood by the reader to convey the meaning explicitly.

According to Karim (2008) states that news writing includes writings in the form of news reports, news reviews and articles about news. In a newspaper, the important part is the news report. A feature of a press report is its specific format. News headlines are usually concise and sometimes do not meet grammatical rules. For example, 'It has been more than a year since my second child of these six siblings left forever and let his death be finally protected', he said while looking at the photo album of the late Hasni Hardi (Harian, 2015). The use of the word 'already a year' carries a vague meaning because it has been more than a year likely to mean two years, two more years and so on. The word more than a year can be interpreted in many ways and less clearly.

Second, changes in meaning according to the context and situation of speech. Another problem statement is the occurrence of changes in meaning according to the context and situation of speech. The word in the Malay language has undergone many changes. Some words have undergone expansion of meaning, narrowing of meaning, change in overall meaning and refinement and targeting of words. Expansion of meaning refers to a word that has one meaning but has undergone a change of meaning so that it can carry another meaning. For example, Harian Metro, 16 October 2015 used the word 'sowing' in the sentence 'The Dutch claim that Russia deliberately' sowed 'confusion' about MH17 '. The word sowing according to Dewan Bahasa dan Pustaka means planting seeds in certain places to germinate. The word 'seed' in the MH17 Tragedy news newspaper carries the definition of deliberately causing confusion of information about the $\mathrm{MH} 17$ incident to the public. The word sowing has undergone a change in meaning referring to the context of the sentence.

\section{Research Objective}

The objectives of this study are as follows to Identify semantics in Berita Harian and Utusan Malaysia newspapers and analyze the comparison of Berita Harian and Utusan Malaysia newspaper 
INTERNATIONAL JOURNAL OF ACADEMIC RESEARCH IN BUSINESS AND SOCIAL SCIENCES Vol. 10, No. 8, 2020, E-ISSN: 2222-6990 @ 2020 HRMARS

\section{Findings of the Study and Discussion}

\section{Identify semantics in Berita Harian and Utusan Malaysia newspapers}

Through the results of the study that has been conducted, the researcher has identified the semantic elements found in the newspaper Berita Harian and Utusan Malaysia. The researcher has listed a total of 14 newspaper news manuscripts, namely seven newspaper articles are from Berita Harian and another seven manuscripts are from Utusan Malaysia. Based on the news press that has been identified, it clearly shows that the newspaper also displays news about the MH17 Tragedy. News of the tragedy has stirred various feelings among the local community. In addition, the press news also gives a sense to the general public about the grief that had to be borne by the family members of the victims of the accident.

Researchers have identified the number of words found in the press news and have a deep semantic element that can make the community also saddened by the fate that has befallen the victims of the MH17 Tragedy. Sources from the newspaper are arranged in ascending order so that developments on the MH17 Tragedy news can be seen clearly and indirectly can show the use of semantic elements in the newspaper.

Based on table 1 it is clear that a total of seven Berita Harian newspaper manuscripts containing semantic elements have been identified.

Table 1: Semantics in the daily News newspaper

\begin{tabular}{|c|c|c|}
\hline Bil & Date & Number of words \\
\hline 1 & 22 August 2014 & $\begin{array}{l}\text { - Linangan air mata pramugara dan pramugari MAS menghiasi } \\
\text { suasana sedih dan pilu di hadapan pintu keluar Kompleks } \\
\text { Bunga Raya KLIA di sini sebaik jenazah mangsa dibawa keluar } \\
\text { oleh kenderaan khas menuju lokasi pengebumian dan } \\
\text { persemadian. } \\
\text { - Saat sedih itu jelas tergambar di rauh wajah mereka, apatah } \\
\text { lagi sebahagiannya sudah berkumpul di hadapan kompleks itu } \\
\text { seawal jam } 9.15 \text { pagi bagi menzahirkan rasa simpati buat } \\
\text { rakan-rakannya yang terkorban dalam nahas tragik MH17 di } \\
\text { timur Ukraine, } 17 \text { Julai lalu. } \\
\text { - Suasana pilu itu turut dikongsi kira-kira } 200 \text { orang awam, } \\
\text { selain pasukan keselamatan dan menyelamat antaranya dari } \\
\text { JPAM serta Angkatan Tentera Malaysia (ATM). } \\
\text { - Sekumpulan berbasikal dikenali 'Cycling For All" turut hadir } \\
\text { menzahirkan simpati kepada.mangsa nahas. } \\
\text { Turut menzahirkan simpati, } 30 \text { ahli keluarga dan saudara } \\
\text { terdekat pembantu juruterbang MAS, Ahmad Hakimi Hanapi } \\
\text { yang berkumpul di laluan keluar kompleks. }\end{array}$ \\
\hline 2 & 26 August 2014 & $\begin{array}{l}\text { - Ketua Komunikasi Strategik MAS, Datuk Najmuddin Abdullah, } \\
\text { berkata bagi memastikan emosi kakitangan yang terjejas tidak } \\
\text { memberi kesan kepada tugasan harian, pihaknya mengambil } \\
\text { inisiatif dengan turun padang menghampiri mereka. }\end{array}$ \\
\hline
\end{tabular}




\begin{tabular}{|c|c|c|}
\hline & & $\begin{array}{l}\text { - Pada masa sama, Najmuddin berharap lebih ramai mangsa } \\
\text { warga negara Malaysia yang terlibat dalam nahas MH17 dapat } \\
\text { dikenal pasti dan dibawa pulang ke tanah air. } \\
\text { - Sementara itu, pramugara MAS, Azerol Hafizi, 26, berkata } \\
\text { ketika ditemui berkata tragedi MAS adalah satu insiden yang } \\
\text { mengejutkan seluruh dunia, namun ia perlu diterima sebagai } \\
\text { ketentuan takdir. } \\
\text { - Ditanya adakah insiden itu 'menakutkannya" untuk terus } \\
\text { berkhidmat di awan biru, Azerol berkata nahas itu langsung } \\
\text { tidak melemahkan semangatnya untuk terus berkhidmat } \\
\text { selagi diperlukan kerana percaya semua yang berlaku adalah } \\
\text { ketentuan llahi. } \\
\text { - Seorang lagi kakitangan MAS yang hanya mahu dikenali } \\
\text { sebagai Ina berkata, selaku penjaga kebajikan kepada keluarga } \\
\text { mangsa, insiden malang itu pastinya tidak dapat dilupakan } \\
\text { sepanjang hayatnya. } \\
\text {-Dari hari pertama insiden, memang sedih sangat sebab kita } \\
\text { tahu nasib malang yang menimpa rakan sejawatan dan } \\
\text { penumpang lain. } \\
\text { - Lepas itu, kita dah dengan sepenuh hati memastikan keluarga } \\
\text { mangsa dapat jagaan yang sepatutnya," katanya sambil } \\
\text { menitiskan air mata. } \\
\text { - Terdahulu, Imam Muda Hafiz atau Mohammad Hafiz Abdul } \\
\text { Khodir dalam tazkirahnya berkata, nahas MH17 bukan hanya } \\
\text { dugaan buat keluarga mangsa, sebaliknya ia satu ujian yang } \\
\text { menuntut umat Islam di seluruh dunia menilai semula diri dan } \\
\text { Julai lalu, selepas ditembak jatuh di wilayah Donetsk, timur } \\
\text { Ukraine. }\end{array}$ \\
\hline 3 & $\begin{array}{c}19 \text { September } \\
2014\end{array}$ & $\begin{array}{l}\text { - Suasana sayu dan pilu menyelubungi istiadat penghormatan } \\
\text { ketenteraan sebaik saja pesawat MH19 yang membawa tiga } \\
\text { jenazah mangsa nahas MH17 tiba di pekarangan Kompleks } \\
\text { Bunga Raya, Lapangan Terbang Antarabangsa Kuala Lumpur } \\
\text { (KLIA) di sini, jam } 8.30 \text { pagi tadi. } \\
\text { - Perasaan sebak jelas kelihatan pada wajah ahli keluarga } \\
\text { mangsa dari kejauhan ketika menyaksikan istiadat berkenaan. } \\
\text { - Selesai majlis penghormatan terakhir kepada jenazah, tempoh } \\
\text { bertafakur selama seminit diumumkan serentak di seluruh } \\
\text { negara tepat jam } 8.48 \text { pagi dengan tetamu yang berada di } \\
\text { landasan Kompleks Bunga Raya juga turut berbuat demikian } \\
\text { mengikut kepercayaan agama masing-masing. }\end{array}$ \\
\hline
\end{tabular}




\begin{tabular}{|c|c|c|}
\hline & & $\begin{array}{l}\text { - Penerbangan MH17 yang membawa } 298 \text { penumpang dan anak } \\
\text { kapal dalam perjalanan dari Amsterdam ke Kuala Lumpur } \\
\text { terhempas selepas ditembak jatuh di timur Ukraine pada } 17 \\
\text { Julai lalu. }\end{array}$ \\
\hline 4 & 2 October 2014 & $\begin{array}{l}\text { - Hishammuddin berkata, sehubungan itu pihak kerajaan amat } \\
\text { mengharapkan semua pihak termasuk media supaya } \\
\text { menghormati kesedihan yang dirasai keluarga mangsa tragedi } \\
\text { MH17, sekali gus bersama-sama menjaga privasi dan sensitiviti } \\
\text { mereka. } \\
\text { - Jumlah ini juga melibatkan } 22 \text { penumpang serta } 15 \text { anak kapal. } \\
\text { - Hishammuddin juga berkata, kerajaan konsisten bahawa pihak } \\
\text { yang bertanggungjawab menembak pesawat MH17 harus } \\
\text { dibawa ke muka pengadilan dan seterusnya menerima } \\
\text { hukuman yang setimpal atas jenayah atau pembunuhan yang } \\
\text { mereka lakukan. }\end{array}$ \\
\hline 5 & 11 July 2015 & $\begin{array}{l}\text { - Program yang turut menghimpunkan waris-waris mangsa } \\
\text { MH17, diadakan secara bersederhana, namun penuh } \\
\text { penghormatan. } \\
\text { - Tayangan slot video berkaitan rentetan peristiwa MH17 dan } \\
\text { sesi bertafakur adalah antara pengisian dan aktiviti yang } \\
\text { dirangka pada majlis pagi ini. } \\
\text { - Penerbangan MH17 yang sedang dalam perjalanan dari } \\
\text { Amsterdam ke Kuala Lumpur terhempas di Ukraine pada } 17 \\
\text { Julai tahun lalu. } \\
\text { - Pesawat itu yang ditembak jatuh di ruang udara wilayah } \\
\text { Donestk, menyebabkan semua } 298 \text { penumpang dan anak } \\
\text { kapal termasuk } 43 \text { warga Malaysia terkorban. }\end{array}$ \\
\hline 6 & 13 October 2015 & $\begin{array}{l}\text { - Hasiah Rajikon, 58, berharap mereka yang terlibat 'membunuh' } \\
\text { anaknya, jurutera berusia } 32 \text { tahun dan semua penumpang, } \\
\text { dihadapkan ke muka pengadilan dengan segera. } \\
\text { - } \text { "Tidak kiralah siapa pun yang menembak kapal terbang itu. Baik } \\
\text { kerajaan Belanda atau Malaysia...heretlah penjenayah itu ke } \\
\text { muka pengadilan segera. } \\
\text { - "Kami sebagai keluarga mangsa nahas mahu mengetahui } \\
\text { kenapa mereka tergamak menembak kapal terbang yang } \\
\text { penumpangnya tidak bersalah langsung," katanya kepada } \\
\text { pemberita ketika ditemui di rumahnya di Taman Seri Alam 2, } \\
\text { Buluh Kasap di sini, hari ini. } \\
\text { - Hasiah berkata, sehingga hari ini walaupun telah menerima } \\
\text { hakikat anaknya telah pergi buat selama-lamanya namun sama } \\
\text { sekali, beliau tidak dapat menerima cara kematian tragis anak } \\
\text { kesayangannya itu. }\end{array}$ \\
\hline
\end{tabular}




\begin{tabular}{|c|c|c|}
\hline & & $\begin{array}{l}\text { - } \quad \text { "Sudah lebih setahun anak kedua saya daripada enam beradik } \\
\text { ini pergi buat selama-lamanya dan biarlah kematiannya ini } \\
\text { terbela akhirnya," katanya sambil membelek album foto } \\
\text { Allahyarham Hasni Hardi. } \\
\text { - Seorang lagi bapa kepada mangsa nahas itu, Md Salim Sarmo, } \\
66 \text {, juga senada dengan Hasiah yang mahukan kebenaran } \\
\text { terhadap tragedi itu ditegakkan melalui undang-undang. } \\
\text { "Kalau diberi tiket untuk kami ke sana mungkinlah boleh } \\
\text { dipertimbangkan tetapi tidak apa, pergi atau tidak hasil } \\
\text { siasatan tetap akan diketahui juga," katanya. }\end{array}$ \\
\hline 7 & 19 October 2015 & 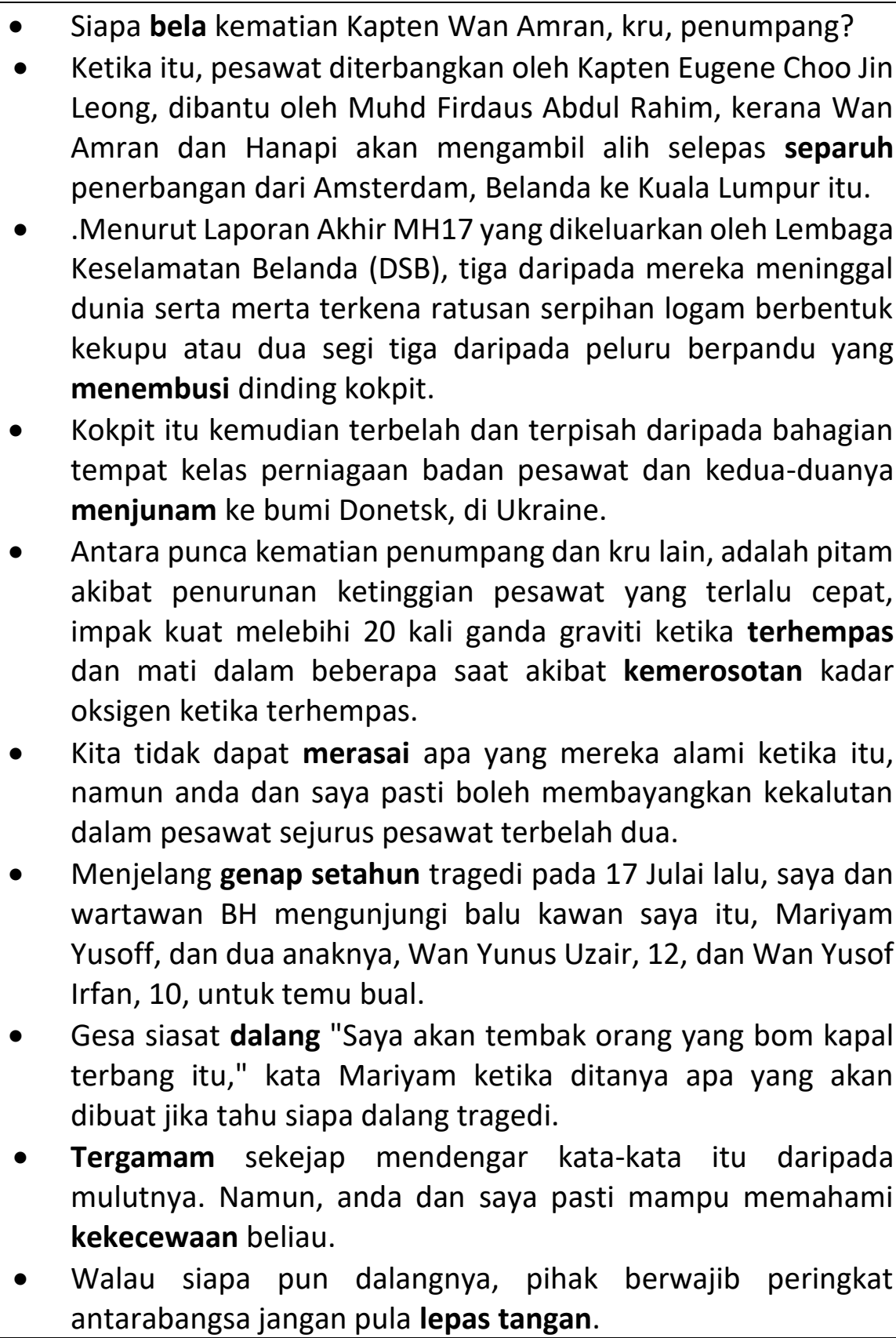 \\
\hline
\end{tabular}




\begin{tabular}{|l|l|}
\hline & $\begin{array}{l}\text { Tak kira sama ada Russia, puak pemisah Republik Rakyat } \\
\text { Donetsk (DPR) atau pihak 'bersekutu' lain, mereka perlu diadili } \\
\text { dan dihukum. }\end{array}$ \\
& $\begin{array}{l}\text { Sekurang-kurangnya, ia dapat melegakan perasaan balu Wan } \\
\text { Amran, dua anaknya dan ratusan lagi waris lain apabila } \\
\text { kematian mereka telah terbela. }\end{array}$ \\
\hline
\end{tabular}

Based on Table 1, it is clear that semantic elements are also found in the Berita Harian newspaper to give a sense to the reader and indirectly allow the community to feel the pain that had to be borne by the families of the victims of the MH17 Tragedy.

Next, the researcher has listed seven news newspaper articles in Utusan Malaysia. Based on the news press that has been identified, it clearly shows that the newspaper also displays news about the MH17 Tragedy. Researchers also list the semantic elements found in the newspaper. Through the newspaper Utusan Malaysia also explained that semantic elements are also used in the newspaper.

Jadual 4.2: Semantik melalui akhbar Utusan Malaysia

\begin{tabular}{|c|c|c|}
\hline Bil & Date & Number of words \\
\hline 1 & 7 December 2014 & $\begin{array}{l}\text { - Menteri Pengangkutan, Datuk Seri Liow Tiong Lai berkata, } \\
\text { sebarang tindakan saman merupakan hak keluarga penumpang } \\
\text { bagi mendapat pembelaan sewajarnya kerana kerajaan juga } \\
\text { sedang membuat tuntutan keadilan yang sama di mahkamah } \\
\text { antarabangsa. } \\
\text { - Dalam konteks itu, jelas beliau, kerajaan akan melakukan apa } \\
\text { sahaja bagi memastikan kes jenayah itu mampu diselesaikan } \\
\text { dan kerja-kerja penyiasatan ke arah itu akan berjaya } \\
\text { menemukan sesuatu. }\end{array}$ \\
\hline 2 & 21 August 2015 & $\begin{array}{l}\text { - Menggadai nyawa dalam keadaan paling berisiko di timur } \\
\text { Ukraine merupakan amanah yang harus dipikul oleh pasukan } \\
\text { forensik Polis Diraja Malaysia (PDRM) bagi mencari baki } \\
\text { serpihan dan bukti berkaitan nahas pesawat Malaysia Airlines } \\
\text { (MAS), MH17 yang ditembak jatuh pada } 17 \text { Julai tahun lalu. } \\
\text { - Pasukan diketuai Komander Pasukan Pengecaman Mangsa } \\
\text { Bencana (DVI), Asisten Komisioner Hussein Omar Khan yang } \\
\text { buat pertama kalinya berkongsi pengalaman sepanjang } \\
\text { menjalankan tugas di wilayah itu memaklumkan, hanya satu } \\
\text { tekad yang membantu beliau menyempurnakan tugas iaitu } \\
\text { keadilan untuk MH17. } \\
\text { "Meskipun pihak berkuasa tempatan memberi jaminan bahawa } \\
\text { gencatan senjata telah dipersetujui tetapi kami masih } \\
\text { mendengar bunyi tembakan, bila-bila masa sahaja mereka } \\
\text { boleh menghala tembakan tepat ke arah kami seperti yang } \\
\text { berlaku ke atas MH17," katanya. }\end{array}$ \\
\hline
\end{tabular}


INTERNATIONAL JOURNAL OF ACADEMIC RESEARCH IN BUSINESS AND SOCIAL SCIENCES Vol. 10, No. 8, 2020, E-ISSN: 2222-6990 @ 2020 HRMARS

\begin{tabular}{|c|c|c|}
\hline 3 & 3 October 2015 & $\begin{array}{l}\text { - "Saya tidak menganggap langkah-langkah ini sebagai proses } \\
\text { penjenamaan semula yang terlalu ketara. la lebih kepada proses } \\
\text { untuk menyegarkan semula jenama," katanya menurut laporan } \\
\text { akhbar Australia, The Sydney Morning Herald, semalam. } \\
\text { - Antara beberapa produk yang berpotensi untuk dinaik taraf itu } \\
\text { termasuklah pesawat A330 MAS yang digunakan untuk } \\
\text { penerbangan ke Australia ketika ini yang tidak menawarkan } \\
\text { tempat duduk baring sepenuhnya bagi kelas perniagaan. }\end{array}$ \\
\hline 4 & 13 October 2015 & $\begin{array}{l}\text { - Katanya, hasil siasatan yang dijalankan selama } 15 \text { bulan itu akan } \\
\text { menjelaskan mengenai apa yang menembak pesawat MH17, } \\
\text { laluan penerbangan di ruang udara Ukraine dan sejauh mana } \\
\text { penumpang pesawat sedar semasa berlakunya nahas tersebut. } \\
\text { - "Kami tidak akan membuat sebarang kenyataan berhubung } \\
\text { liabiliti atau siapa yang bertanggungjawab menembak jatuh } \\
\text { pesawat kerana persoalan itu telah diserahkan kepada siasatan } \\
\text { jenayah Pasukan Penyiasatan Bersama (JIT)," katanya hari ini. } \\
\text { - Bangkai pesawat MH17 telah dibawa dari timur Ukraine ke } \\
\text { Pangkalan Tentera Udara Belanda di Gilzerijen pada Disember } \\
\text { lalu. } \\
\text { DSB juga akan menunjukkan kepada media sebahagian pesawat } \\
\text { yang telah dibina semula iaitu bahagian kokpit dan kelas } \\
\text { perniagaan yang menerima impak keluaran yang kuat. } \\
\text { baporan awal yang dikeluarkan DSB mendedahkan pesawat } \\
\text { sebenaan ditembusi oleh beberapa objek berkuasa tinggi } \\
\text { sebelum berkecai di udara. }\end{array}$ \\
\hline 5 & 14 October 2015 & $\begin{array}{l}\text { - Malaysia komited membawa pihak yang bertanggungjawab } \\
\text { menembak jatuh pesawat Malaysia Airlines (MAS) MH17 ke } \\
\text { muka pengadilan selepas Lembaga Keselamatan Belanda (DSB) } \\
\text { mengeluarkan laporan berhubung nahas itu di Ukraine tahun } \\
\text { lalu. } \\
\text { - Katanya, hasil laporan tersebut kini akan membuka jalan bagi } \\
\text { tindakan selanjutnya untuk memastikan dalang yang } \\
\text { bertanggungjawab berdepan dengan hukuman terhadap } \\
\text { jenayah pembunuhan yang dilakukannya. } \\
\text { "15 bulan telah berlalu sejak nahas kejadian tersebut, namun } \\
\text { komitmen bagi mengheret pelaku jenayah ke muka pengadilan } \\
\text { kekal teguh apabila } 298 \text { nyawa termasuk } 43 \text { rakyat Malaysia } \\
\text { yang tidak bersalah terbunuh dalam kejadian malang itu. } \\
\text { "Penyiasatan yang masih dijalankan dan diketuai oleh Belanda } \\
\text { perlu menjawab pelbagai persoalan serta memberi ruang } \\
\text { seluasnya bagi mengenakan tindakan paling maksimum } \\
\text { terhadap pihak yang bertanggungjawab," katanya dalam satu } \\
\text { kenyataan di sini malam ini. }\end{array}$ \\
\hline
\end{tabular}




\begin{tabular}{|c|c|c|}
\hline & & $\begin{array}{l}\text { - Menurut Najib, peristiwa itu merupakan satu perjalanan yang } \\
\text { sukar terutama buat ahli keluarga yang telah kehilangan insan } \\
\text { yang tersayang dalam nahas pada } 17 \text { Julai } 2014 \text { itu yang akan } \\
\text { sentiasa diingati dalam ingatan dan doa. } \\
\text { - "Namun demikian, saya berjanji Malaysia akan kekal menuntut } \\
\text { keadilan sehingga dalang di sebalik kejadian tersebut menerima } \\
\text { hukuman yang setimpal," katanya. }\end{array}$ \\
\hline 6 & 15 October 2015 & $\begin{array}{l}\text { - Ibu bapa kepada Allahyarham Azrina Yakob, 41, pramugari } \\
\text { pesawat Malaysia Airlines (MAS) MH17 yang ditembak jatuh di } \\
\text { ruang udara Ukraine mahu pihak yang bertanggungjawab } \\
\text { menembak pesawat tersebut dihadapkan ke muka pengadilan } \\
\text { dengan segera. } \\
\text { - Pasukan penyiasat antarabangsa semalam merumuskan } \\
\text { bahawa pesawat MH17 ditembak jatuh oleh peluru berpandu } \\
\text { BUK buatan Rusia. }\end{array}$ \\
\hline 7 & 17 October 2015 & $\begin{array}{l}\text { - "Bagaimanapun, perkara paling utama kepada kita adalah untuk } \\
\text { menuntut keadilan bagi mangsa-mangsa pesawat itu serta } \\
\text { katanya. } \\
\text { - Yermolov berkata, Rusia sedia bekerjasama bukan sahaja } \\
\text { dengan Malaysia tetapi negara terlibat yang lain untuk mencari } \\
\text { dalang di sebalik nahas MH17 dan membawanya ke muka } \\
\text { pengadilan. } \\
\text { - Mengulas lanjut, Reezal Merican berkata, pihaknya akan } \\
\text { berusaha mencari sebanyak mungkin bukti untuk menuntut } \\
\text { keadilan kepada mangsa-mangsa pesawat berkenaan. } \\
\text { - Semuanya akan disemak dan kita akan memastikan tidak ada } \\
\text { perkara yang disembunyikan," jelasnya. }\end{array}$ \\
\hline
\end{tabular}

Based on table 4.2 clearly shows a total of seven news articles from Utusan Malaysia newspaper that have been used as a reference source.

\section{The Comparison of Berita Harian and Utusan Malaysia Newspapers}

Based on the table below clearly shows that there are differences in the use of semantics in the two newspapers. The highest use of semantics in the Berita Harian newspaper was recorded on 19 October 2015, which recorded 14 words. Next, the use of moderate semantics recorded on 26 August 2014 recorded as many as one word and the use of the least or least semantic element was recorded on October 2, 2014 by recording only three words only. Meanwhile, it is different from the news of the Utusan Malaysia newspaper which recorded the highest number of semantic element usage on 14 October 2015 which recorded seven words. Subsequently, the moderate number of semantic element usage was recorded on 21 August 2015 and 17 October 2015 with the number of four words respectively. In addition, the lowest or least use of semantic elements was recorded on 7 December 2014, 3 October 2015 and 15 October 2015 by recording as many as 2 words. 
INTERNATIONAL JOURNAL OF ACADEMIC RESEARCH IN BUSINESS AND SOCIAL SCIENCES Vol. 10, No. 8, 2020, E-ISSN: 2222-6990 @ 2020 HRMARS

Therefore, there are differences between the two newspapers regarding the use of semantic elements. Thus, through table 3 and table 4 can clearly show the use of the highest semantic elements is through the newspaper Berita Harian. This situation shows that the use of semantic elements in the press is very important because it can provide space for the community to think for a moment about the input that has been commented on by the author. The use of semantic elements in the press can give an idea of the writer's concern for the tragedy that befell the victims of $\mathrm{MH} 17$ and the families of the victims. The use of language that has a connotative element that is the use of implicit meaning clearly illustrates the writer's sensitivity to the sensitivity of the victim's family that they need to take care of. Therefore, the use of semantic elements is very necessary in the press news to ensure that the feelings of the victim's family are taken care of as best as possible.

Overall, it clearly shows that Berita Harian newspaper has the highest use of semantic elements on 19 October 2015. The use of the second highest semantic element was also recorded by Berita Harian newspaper on 26 August 2014. Furthermore, the third highest was recorded by Utusan Malaysia news newspaper on 14 October. 2015 and the fourth highest semantic element was also recorded by Utusan Malaysia newspaper on 21 August 2015 and 17 October 2015. In addition, the fifth highest number of semantics recorded on 2 October 2014 was represented by Berita Harian newspaper and the least number of semantic element usage is on December 7, 2014. This situation clearly shows the difference between the use of semantic elements in the two news newspapers. Based on table 3 and table 4 clearly shows the scale of using the highest semantic element between Berita Harian newspaper and Utusan Online.

Table 3 shows the total use of semantic elements in the Daily News newspaper starting from the highest, medium and lowest scales.

Table 3: Total semantics of the Daily News newspaper

\begin{tabular}{|c|c|c|c|}
\hline BI & Scala & Date & Semantic number \\
\hline 1 & height & 19 October 2015 & 14 \\
2 & moderate & 26 Augusts 2014 & 9 \\
3 & low & 2 October 2014 & 3 \\
\hline
\end{tabular}

Based on table 3, it is clear that the highest use of semantic elements was recorded on 19 October 2015.

Table 4 shows the total use of semantic elements in Utusan Malaysia

\begin{tabular}{|c|c|c|c|}
\hline Bil & Scala & Date & Semantic number \\
\hline 1 & Height & 14 October 2015 & 7 \\
2 & Moderate & 21 Ausgust 2015 & 4 \\
3 & Low & 17 October 2015 & 2 \\
& & 7 Dicember 2014 \\
\hline
\end{tabular}

Based on table 4, it is clear that the highest use of semantic elements was recorded on 14 October 2015. 
INTERNATIONAL JOURNAL OF ACADEMIC RESEARCH IN BUSINESS AND SOCIAL SCIENCES Vol. 10, No. 8, 2020, E-ISSN: 2222-6990 @ 2020 HRMARS

\section{The Explain the Semantic Meaning in Berita Harian and Utusan Malaysia Newspapers}

Tables 5 and 6 show a description of the semantic meaning found in Berita Harian and Utusan Malaysia newspapers. Researchers have described the meaning of semantics in the newspaper to find out the level of effectiveness of the use of semantic elements in both newspapers. In addition, the researcher has taken some of the fish found in both newspapers to be used as a result of the study. The researcher used 10 excerpts from Berita Harian newspaper and 10 excerpts from Utusan Malaysia. A total of 20 passages will be given a description of the meaning contained in the passage. The description of the meaning of the word is explained in two structures, namely through the meaning of the Dictionary and through the meaning of the newspaper itself.

Clearly shows there are different meanings from the actual meaning of the dictionary and the meaning used in newspaper news. This situation shows that meaning in semantics has an implicit meaning. Appropriate semantic elements are used in newspaper news to prevent the victim's family from feeling burdened with the news newspaper written by the author.

Based on table 5 shows the semantic meaning according to the meaning of the dictionary and the meaning of the newspaper found in the Daily News newspaper.

Table 5: The semantic meaning in the Daily News newspaper

\begin{tabular}{|l|l|l|l|}
\hline Bil & \multicolumn{1}{|c|}{ Data } & $\begin{array}{l}\text { Meaning of the } \\
\text { dictionary }\end{array}$ & $\begin{array}{l}\text { Meaning of the news } \\
\text { context }\end{array}$ \\
\hline 1 & $\begin{array}{l}\text { Walaupun sudah dua tahun insiden } \\
\text { itu berlalu, katanya, ingatan terhadap } \\
\text { arwah anaknya tidak pernah pudar. }\end{array}$ & $\begin{array}{l}\text { Not bright or fuzzy } \\
\text { colors }\end{array}$ & $\begin{array}{l}\text { Never fade from } \\
\text { memory }\end{array}$ \\
\hline 2 & $\begin{array}{l}\text { "Tindakan memasang dan mengibar } \\
\text { Jalur Gemilang lebih bermakna lagi } \\
\text { sebab rasa dan jiwa patriotisme tidak } \\
\text { boleh tersimpan dalam jiwa tetapi } \\
\text { perlu dizahirkan secara terbuka bagi } \\
\text { menunjukkan semangat rakyat } \\
\text { Malaysia," katanya pada majlis } \\
\text { pelancaran sambutan Bulan } \\
\text { Kemerdekaan dan Kempen Kibar Jalur } \\
\text { Gemilang di sini hari ini. }\end{array}$ & Really visible \\
\hline 3 & $\begin{array}{l}\text { Sebuah papan tanda gergasi turut } \\
\text { diletakkan di hadapan Perbadanan } \\
\text { Putrajaya sebagai tempat orang ramai } \\
\text { menurunkan tandatangan dalam } \\
\text { menyampaikan ucapan takziah } \\
\text { terhadap mangsa insiden pesawat } \\
\text { MH17 dan MH370. }\end{array}$ & $\begin{array}{l}\text { Very large and } \\
\text { believed creatures } \\
\text { eat people }\end{array}$ & $\begin{array}{l}\text { Something big is } \\
\text { described as a giant }\end{array}$ \\
\hline 4 & $\begin{array}{l}\text { "Apabila di dalam lubuk hati kita, di } \\
\text { dalam jiwa kita, di dalam roh kita, kita } \\
\text { dapat hayati rasa cinta kepada negara, }\end{array}$ & $\begin{array}{l}\text { Deep part of the river } \\
\text { or sea }\end{array}$ & Deep part of the river \\
or sea
\end{tabular}


INTERNATIONAL JOURNAL OF ACADEMIC RESEARCH IN BUSINESS AND SOCIAL SCIENCES Vol. 10, No. 8, 2020, E-ISSN: 2222-6990 @ 2020 HRMARS

\begin{tabular}{|c|c|c|c|}
\hline & $\begin{array}{l}\text { maka kita akan melakukan apa sahaja } \\
\text { demi kepentingan bangsa, agama dan } \\
\text { negara. }\end{array}$ & & \\
\hline 5 & $\begin{array}{l}\text { Ketua Komunikasi Strategik MAS, } \\
\text { Datuk Najmuddin Abdullah, berkata } \\
\text { bagi memastikan emosi kakitangan } \\
\text { yang terjejas tidak memberi kesan } \\
\text { kepada tugasan harian, pihaknya } \\
\text { mengambil inisiatif dengan turun } \\
\text { padang menghampiri mereka. }\end{array}$ & Open land & $\begin{array}{l}\text { Take the initiative } \\
\text { together to motivate } \\
\text { the other crew }\end{array}$ \\
\hline 6 & $\begin{array}{l}\text { "Terima kasih pada kerajaan yang } \\
\text { prihatin terhadap waris mangsa } \\
\text { penumpang dan anak kapal MH17 } \\
\text { yang mahu membawa perkara dan } \\
\text { penemuan terbaru ini ke muka } \\
\text { pengadilan," katanya. }\end{array}$ & $\begin{array}{l}\text { Appearance of a } \\
\text { person's level }\end{array}$ & $\begin{array}{l}\text { Taken to court for } \\
\text { trial }\end{array}$ \\
\hline 7 & $\begin{array}{l}\text { Seorang lagi bapa kepada mangsa } \\
\text { nahas itu, Md Salim Sarmo, 66, juga } \\
\text { senada dengan Hasiah yang mahukan } \\
\text { kebenaran terhadap tragedi itu } \\
\text { ditegakkan melalui undang-undang. }\end{array}$ & $\begin{array}{l}\text { Appropriate colors / } \\
\text { tones of clothing that } \\
\text { have similarities }\end{array}$ & $\begin{array}{l}\text { Have the same } \\
\text { opinion }\end{array}$ \\
\hline 8 & $\begin{array}{l}\text { Mendiang Ng Shi Ing, pensyarah } \\
\text { Universiti Malaysia Sabah (UMS), } \\
\text { mangsa nahas pesawat Malaysia } \\
\text { Airlines (MAS) MH17, akan sentiasa } \\
\text { dikenang oleh pelajarnya, seorang } \\
\text { pendidik yang berdedikasi dan } \\
\text { menyampaikan ilmu tanpa } \\
\text { bersandarkan buku semata-mata. }\end{array}$ & $\begin{array}{l}\text { Sit or stand while } \\
\text { applying the body to } \\
\text { something so that it } \\
\text { is firm or comfortable }\end{array}$ & $\begin{array}{l}\text { Sit or stand while } \\
\text { applying the body to } \\
\text { something so that it is } \\
\text { firm or comfortable }\end{array}$ \\
\hline 9 & $\begin{array}{l}\text { Surat yang menyertakan } 12 \text { lampiran } \\
\text { mengandungi hasil penemuan pakar } \\
\text { Russia kepada DSB itu, antaranya } \\
\text { menyebut lubang penembusan pada } \\
\text { bangkai pesawat tidak konsisten } \\
\text { dengan letupan yang biasanya } \\
\text { dihasilkan oleh peledak 9N314M, } \\
\text { selain mendakwa lokasi di mana } \\
\text { peluru berpandu dilancarkan tidak } \\
\text { dikira secara tepat. }\end{array}$ & $\begin{array}{l}\text { The structure of an } \\
\text { object that has been } \\
\text { dug up and caused to } \\
\text { bend }\end{array}$ & A plane leak \\
\hline 10 & $\begin{array}{l}\text { Lampiran itu turut menyatakan } \\
\text { bahawa penerangan mengenai } \\
\text { serpihan seperti dinyatakan dalam } \\
\text { laporan tidak sama dengan serpihan } \\
\text { peledak 9N314M selain kedudukan }\end{array}$ & $\begin{array}{l}\text { Something that } \\
\text { squirts or shines out }\end{array}$ & $\begin{array}{l}\text { Fragments of aircraft } \\
\text { body parts }\end{array}$ \\
\hline
\end{tabular}


INTERNATIONAL JOURNAL OF ACADEMIC RESEARCH IN BUSINESS AND SOCIAL SCIENCES Vol. 10, No. 8, 2020, E-ISSN: 2222-6990 @ 2020 HRMARS

peluru berpandu ketika letupan
berlaku tidak sepadan dengan
semburan serpihan pada badan
pesawat yang ditemui terhempas.

Based on table 5, clearly shows the semantic elements found in dictionary meanings and meanings from newspaper sources.

Based on table 6 shows the semantic meaning according to the meaning of the dictionary and the meaning of the newspaper found in the newspaper Utusan Malaysia.

Table 6: The semantic meaning in the Utusan Malaysia newspaper

\begin{tabular}{|c|c|c|c|}
\hline Bil & Data & $\begin{array}{l}\text { Meaning of the } \\
\text { dictionary }\end{array}$ & $\begin{array}{l}\text { Meaning of the news } \\
\text { context }\end{array}$ \\
\hline 1 & $\begin{array}{l}\text { "Dah masuk dua tahun kami } \\
\text { kehilangan Noor Rahimah tetapi } \\
\text { benda tu (siasatan) masih tergantung } \\
\text { tanpa sebarang jawapan yang pasti," } \\
\text { katanya. }\end{array}$ & $\begin{array}{l}\text { Something man- } \\
\text { made }\end{array}$ & $\begin{array}{l}\text { Report on the MH17 } \\
\text { Tragedy }\end{array}$ \\
\hline 2 & $\begin{array}{l}\text { "Kita sudah mendapat laporan } \\
\text { daripada pasukan penyiasat yang } \\
\text { disertai Belanda dan Australia. } \\
\text { Semuanya akan disemak dan kita akan } \\
\text { memastikan tidak ada perkara yang } \\
\text { disembunyikan," jelasnya. }\end{array}$ & Bush & Examined \\
\hline 3 & $\begin{array}{l}\text { Bagi Amna Mohd, Shariff, 65, sebagai } \\
\text { ibu yang kehilangan anak tercinta, } \\
\text { Allahyarham Mohd. Noor Shaikh } \\
\text { Mahmood, 44, dalam tragedi malang } \\
\text { itu, beliau menyerahkan kepada } \\
\text { kebijaksanaan pihak berkuasa untuk } \\
\text { menuntut bela diatas kematian semua } \\
\text { penumpang MH17. }\end{array}$ & $\begin{array}{l}\text { Caring for or } \\
\text { preserving }\end{array}$ & Demanding justice \\
\hline 4 & $\begin{array}{l}\text { "Malaysia dan Belanda harus } \\
\text { mengheret mereka bertanggungjawab } \\
\text { ke muka pengadilan meskipun kita } \\
\text { faham itu bukan mudah kerana } \\
\text { melibatkan kuasa besar. }\end{array}$ & $\begin{array}{l}\text { Attracting criminals } \\
\text { to court }\end{array}$ & $\begin{array}{l}\text { Attracting criminals to } \\
\text { court }\end{array}$ \\
\hline 5 & $\begin{array}{l}\text { Dengan memetik tiga sumber yang } \\
\text { rapat dengan siasatan itu, akhbar } \\
\text { berkenaan menyatakan, siasatan yang } \\
\text { diketuai Belanda mendapati, pesawat } \\
\text { berkenaan terkena peluru berpandu } \\
\text { permukaan ke udara BUK semasa }\end{array}$ & $\begin{array}{l}\text { Take something } \\
\text { from the handle }\end{array}$ & $\begin{array}{l}\text { Obtain information on } \\
\text { the investigation }\end{array}$ \\
\hline
\end{tabular}


INTERNATIONAL JOURNAL OF ACADEMIC RESEARCH IN BUSINESS AND SOCIAL SCIENCES Vol. 10, No. 8, 2020, E-ISSN: 2222-6990 @ 2020 HRMARS

\begin{tabular}{|c|c|c|c|}
\hline & $\begin{array}{l}\text { dalam penerbangan dari Amsterdam } \\
\text { ke Kuala Lumpur. }\end{array}$ & & \\
\hline 6 & $\begin{array}{l}\text { Katanya, hasil laporan tersebut kini } \\
\text { akan membuka jalan bagi tindakan } \\
\text { selanjutnya untuk memastikan dalang } \\
\text { yang bertanggungjawab berdepan } \\
\text { dengan hukuman terhadap jenayah } \\
\text { pembunuhan yang dilakukannya. }\end{array}$ & Create a new path & Give space \\
\hline 7 & $\begin{array}{l}\text { Bangkai pesawat } \mathrm{MH} 17 \text { telah dibawa } \\
\text { dari timur Ukraine ke Pangkalan } \\
\text { Tentera Udara Belanda di Gilzerijen } \\
\text { pada Disember lalu. }\end{array}$ & $\begin{array}{l}\text { Something that is } \\
\text { dead and rotting }\end{array}$ & Aircraft frame \\
\hline 8 & $\begin{array}{l}\text { "Jadi, kita tunggu dulu laporan akhir itu } \\
\text { keluar Oktober ini dan kita harap } \\
\text { laporan itu nanti akan turut } \\
\text { mendedahkan tentang 'objek } \\
\text { berkuasa tinggi' yang terkandung } \\
\text { dalam laporan awal. }\end{array}$ & $\begin{array}{l}\text { Something that has } \\
\text { a right }\end{array}$ & Missile \\
\hline 9 & $\begin{array}{l}\text { "Tidak patutlah saya mendedahkan } \\
\text { kandungan laporan itu kerana ia } \\
\text { belum dimuktamadkan dan ia } \\
\text { sepatutnya dimuktamadkan oleh } \\
\text { mereka (pasukan penyiasat Belanda). }\end{array}$ & $\begin{array}{l}\text { Fill out the final } \\
\text { report }\end{array}$ & Fill out the final report \\
\hline 10 & $\begin{array}{l}\text { Meskipun hujan renyai-renyai, } \\
\text { keadaan tersebut tidak melunturkan } \\
\text { semangat orang ramai bagi } \\
\text { menjayakan program tersebut. }\end{array}$ & Fades & Weakning \\
\hline
\end{tabular}

Based on table 6, clearly shows the semantic elements found in dictionary meanings and meanings from newspaper sources.

Through the 20 passages that have been studied in the two newspapers, the researcher will only focus on 6 passages, namely 3 passages from Berita Harian newspaper and 3 passages from Utusan Malaysia. The first word chosen by the researcher is the word... depth.... According to the Dewan Bahasa dan Pustaka dictionary (2016) the second edition student dictionary carries the meaning of the deep river or sea part. In contrast to the meaning found in the newspaper Berita Harian which carries meaning in the soul or space of a person's heart. The use of the word lubuk describes the asceticism in which the feelings that the community must immerse and understand to feel the meaning of love for the country despite various calamities. Lubuk is the deepest part of the river that can give the impression that the community needs to love the homeland no matter what happens and that spirit needs to be born from a conscience to ensure that the spirit of love for the country continues to flourish in the heart of every nation without any prejudice. 
INTERNATIONAL JOURNAL OF ACADEMIC RESEARCH IN BUSINESS AND SOCIAL SCIENCES Vol. 10, No. 8, 2020, E-ISSN: 2222-6990 @ 2020 HRMARS

Researchers look at it from the point of view of semantic meaning that has a deeper impact on the reader. After reading the article clearly shows the reader will better understand the real meaning through the approach of semantic elements in the newspaper because after reading it the reader will think about the meaning and message to be conveyed.

Next, the word that has been selected by the researcher is... hole... According to the dictionary of Dewan Bahasa dan Pustaka (2016) fourth edition states that the meaning of the word explains about the structure of an object that has been dug and causes curvature. In contrast to the meaning of the newspaper which explains that there is a leak in the frame of the aircraft. Readers will understand the meaning based on the passage rather than the meaning of the dictionary. After research and studies that have been conducted it was found that the meaning of the hole indicates a leak that occurs as a result of the impact of the shot hit on the fuselage. This clearly shows the reader is more understanding of the deeper meaning through news outlets that have used a semantic approach to cover up the rough meaning to prevent the victim's family from being burdened with articles that do not maintain their sensitivity as members who have lost their family members.

Also, the third word selection is... spray.... According to the meaning of the dictionary describes something that squirts or radiates out. Through the interpretation of the meaning found in the passage explains about the pieces or fragments that are stuck on the body of the aircraft. As a reader will give more understanding on the meaning of the passage because it can give a deeper meaning and better understand the meaning to be conveyed even though the original meaning of the word has changed. This situation is due to the author wants to give an idea of what happened and be able to dive into the situation that occurred.

Further, through three excerpts selected in the Utusan Malaysia newspaper, the researcher has chosen the word... pave the way.... According to the Dewan Bahasa dan Pustaka dictionary, it means making a new path. In contrast to the meaning of the newspaper which carries the meaning of giving space. Through reading the newspaper clearly shows the level of understanding through the newspaper is easier to understand and can give an idea of what you want to convey. Opening the way is used to highlight the softness in the language and aims to give an implicit meaning to a meaning behind the words that are expressed.

In addition, the researcher also chooses the word... content .... According to the dictionary of Dewan Bahasa dan Pustaka carries the meaning of anything contained in something or refers to the baby in the womb. Through the meaning found in the press refers to the content of the final report that has been written based on the results of the investigation that has been conducted. Thus, the reader will give an interpretation based on the context of the situation expressed. After reading, it was found that the level of understanding of the meaning of the word is easier to understand according to the meaning of the newspaper than the meaning of the dictionary.

The last word that the researcher chooses is the word... bleach .... According to the dictionary of Dewan Bahasa dan Pustaka carries the meaning fade. Often used to explain the color of clothing. But there is a difference in the meaning of the press which gives the meaning of weakening or dampening the spirit to be in the assembly of the ceremony held even in the face of unfavorable weather factors. 
INTERNATIONAL JOURNAL OF ACADEMIC RESEARCH IN BUSINESS AND SOCIAL SCIENCES Vol. 10, No. 8, 2020, E-ISSN: 2222-6990 @ 2020 HRMARS

The results of the study conducted found that the use of semantic elements in the press news can cause readers and the local community to be impressed and touched due to the occurrence of unexpected and absurd tragedies. The actions that have been done on the aircraft seem to have lost their humanity to the point of causing this to happen.

Based on the six words that have been described, it is found that the word refers to structural semantics which emphasizes on one of the grammatical components that specializes in semantic representation of sentences. Structural semantics use distinctive features and look at the relationship between those features to determine the accuracy of the formula. Similar interpretations can form synonyms. For example the words teenager and bachelor. Next, dissimilar interpretations form antonyms. For example women and men.

Moreover, the interpretation of structural semantic meaning is based on the analysis of phonetic representations. This situation gives an explanation of the study made is based on sentences but only words are given meaning. Semantics at this stage has directly set aside meaning at the sentence level. In fact, semantics at this stage has assumed that the semantic features of a word in a sentence can be combined to get the meaning of the whole sentence but the sentence structure must be similar. However, semantics at the structural level fails because semantics is found to be unable to stand on its own. Some sentences will be vague and can not be proven and can not give a clear meaning because it can be interpreted from various different human points of view.

Such a situation causes the structural semantics to cease to the point of listing the form of sentence meaning based on word by word. Indirectly set aside the relationship of internal and external structure of the sentence because it can not provide a more detailed explanation for the meaning of the words listed.

\section{Conclusion}

The semantic elements used in the press news can have a positive impact on the readers because they can together dive into the feelings of the families of the victims involved. Clearly, through the use of semantic elements can make sense to the reader and indirectly can ensure that the words used are not excessive.

\section{References}

Ab. H. N. (2014). Peluasan Semantik Kata Sifat Ringan: Satu Analisis Model Jaringan Langacker (1988). http://journalarticle.ukm.my/8575/1/8000-20844-1-SM.pdf (retrevied on 27 September 2016).

Abd. G. R. (1998). Perkembangan Semasa Teori Semantik. Kuala Lumpur: Dewan Bahasa dan Pustaka.

Abd. G. Z. (1994). Bahasa, Makna dan Konteks. Kuala Lumpur: Dewan Bahasa da Pustaka. Aminuddin, M. P. (2005). Semantik: Pengantar Studi tentang Makna. C.V.Sinar Baru: Bandung. Dwi, A. (2011). Prinsip Pollyanna dalam Wacana Dakwah (Kajian Pragmatik).

Hamzah, Z. A. Z. (2014). Semantik Struktural. Serdang: Fakulti Bahasa Moden dan Komunikasi, Universiti Putra Malaysia.

Hassan, A. (1989). Semantik. Kuala Lumpur: Dewan Bahasa dan Pustaka. 
INTERNATIONAL JOURNAL OF ACADEMIC RESEARCH IN BUSINESS AND SOCIAL SCIENCES Vol. 10, No. 8, 2020, E-ISSN: 2222-6990 @ 2020 HRMARS

Ho-A, I. (2011). Analisis Kognitif Semantik Peribahasa Melayu Bersumberkan Anjing (Canis Familiaris). http://journalarticle.ukm.my/994/1/pp125_141.pdf. (retrevied on 27 September 2016). https://publikasiilmiah.ums.ac.id/bitstream (retrevied on 27 September 2016).

Isam, H., \& Mat, A. N. (2012). Nilai Setia dari Perspektif Prosodi Semantik: Analisis Berbantu Data Korpus. http://journalarticle.ukm.my/4909/1/pp\%2520359_374.pdf (retrevied on 27 September 2016).

Isam, H., \& Mat, A. N. (2011). Analisis Berasaskan Korpus dalam Menstruktur Semula Kedudukan Makna Teras Leksikal Setia. http://journalarticle.ukm.my/995/1/pp143_158.pdf (retrevied on 27 September 2016).

Jalaluddin, N. H. (1993). Semantik dan Pragmatik: Satu Pengenalan. Kuala Lumpur: Dewan Bahasa dan Pustaka.

Kader, M. (1996). Menerokai Struktur Semantik. Kuala Lumpur: Dewan Bahasa dan Pustaka.

Karim, N. S., \& Jamaluddin, N. (2003). Bahasa Melayu STPM.

Musa, H., \& Guan, O. C. (1998). Pengantar Ilmu Makna. Kuala Lumpur: Dewan Bahasa dan Pustaka.

Othman, S. S., \& Mat, N. L. (2013). Pemilihan Berita dari PerspektifWartawan Media Cetak di Malaysia. http://www.ukm.my/jkom/journal/pdf_files/2013/V29_2_51-68.pdf (retrevied on 27 September 2016).

Rulli, C. S. (2014). Analisis Semiotika Terhadap Makna Jihad dalam Film Zero DarkThirty. http://repository.uinjkt.ac.id/dspace/bitstream (retrevied on 27 September 2016).

Sew, J. W. (2011). Pandangan Alternatif pada Analisis Semantik Kognitiflmbuhan BeR.http://journalarticle.ukm.my/1006/1/155-170.pdf (retrevied on 27 September 2016).

Shahari, N. (2015) Utusan Malaysia http://www.utusan.com.my/berita/nasional/waris-mangsasokong-komitmen-malaysia-1.146646 (retrevied on 23 September 2016).

Yusof, M., \& Harun, K. (2015) Analisis Lakuan Tutur dalam Ruangan Status Facebook. http://www.ukm.my/jkom/journal/pdf_files/2015/V31_2_10.pdf (retrevied on 27 September 2016). 